\title{
Prevention of Cutaneous Tissue Contracture During Removal of Craniofacial Implant Superstructures for CT and MRI Studies
}

\author{
Maureen Sullivan ${ }^{1}$, Rachael Rossitto ${ }^{1}$, David Casey ${ }^{1}$ \\ ${ }^{1}$ Department of Dentistry and Maxillofacial Prosthetics, Roswell Park Cancer Institute, Elm and Carlton Streets, Buffalo, \\ N.Y., USA.
}

\author{
Corresponding Author: \\ David M. Casey \\ Department of Dentistry and Maxillofacial Prosthetics \\ Roswell Park Cancer Institute \\ Elm and Carlton Streets \\ NY 14263, Buffalo, New York \\ USA \\ Phone: 7168455972 \\ Fax: 7168453061 \\ E-mail: david.casey@,roswellpark.org
}

\begin{abstract}
Objectives: Head and neck cancer patients who have lost facial parts following surgical intervention frequently require craniofacial implant retained facial prostheses for restoration. Many craniofacial implant patients require computed tomography and magnetic resonance imaging scans as part of their long-term follow-up care. Consequently removal of implant superstructures and peri-abutment tissue management is required for those studies. The purpose of the present paper was to describe a method for eliminating cranial imaging artifacts in patients with craniofacial implants.

Material and Methods: Three patients wearing extraoral implant retained facial prostheses needing either computed tomography or magnetic resonance imaging studies were discussed. Peri-implant soft tissues contracture after removal of percutaneous craniofacial implant abutments during computed tomography and magnetic resonance imaging studies was prevented using a method proposed by authors. The procedure involves temporary removal of the supra-implant components prior to imaging and filling of the tissue openings with polyvinyl siloxane dental impression material.

Results: Immediately after filling of the tissue openings with polyvinyl siloxane dental impression material patients were sent for the imaging studies, and were asked to return for removal of the silicone plugs and reconnection of all superstructure hardware after imaging procedures were complete. The silicone plugs were easily removed with a dental explorer. The percutaneous abutments were immediately replaced and screwed into the implants which were at the bone level.

Conclusions: Presented herein method eliminates the source of artifacts and prevents contracture of percutaneous tissues upon removal of the implant abutments during imaging.
\end{abstract}

Keywords: endosseous implantation; computed tomography, X-ray; magnetic resonance imaging; artifacts.

Accepted for publication: 4 April 2010

To cite this article:

Sullivan M, Rossitto R, Casey DM. Prevention of Cutaneous Tissue Contracture During Removal of Craniofacial Implant Superstructures for CT and MRI Studies.

J Oral Maxillofac Res 2010 (Apr-Jun);1(2):e4

URL: http://www.ejomr.org/JOMR/archives/2010/2/e4/e4ht.pdf

doi:10.5037/jomr.2010.1204 


\section{INTRODUCTION}

Imaging techniques such as computed tomography (CT) and magnetic resonance imaging (MRI) are routinely used for diagnosis, treatment planning, and monitoring disease progression or recurrence in head and neck cancer patients. Many patients who have lost facial structures secondary to cancer surgery require craniofacial implant retained facial prostheses for restoration of appearance. These include auricular, nasal, orbital, or combination prostheses. Facial prosthesis retention by titanium craniofacial endosseous implants has become state of the art treatment since first reported by Tjellström et al. [1,2]. Tjellström and Brånemark's pioneering work using titanium craniofacial osseointegrated implants was an consequence of Brånemark's earlier work developing the titanium intraoral osseointegrated implant $[\underline{3}, \underline{4}]$.

Endosseous implants are small (3 - $5 \mathrm{~mm}$ in length), made of titanium, and by themselves do not cause significant artifacts on CT or MRI. Attached to the implants however, are abutments and superstructures of other metals which may include gold alloys and ferromagnetic materials (Figure 1). These abutments and superstructures can cause localized artifacts and image distortion in CT and MRI scans contributing to difficulties in interpretation and subsequently reducing their diagnostic accuracy (Figure 2A) [5-13] .

The various array of retention systems used to attach the facial prostheses to the craniofacial implants can be intimidating to the uninitiated radiologist or technician [14]. The titanium craniofacial implant itself ends at bone level. There is always a second part, the abutment that connects to the implant and perforated the cutaneous tissue. The abutment also is always titanium. Connected to the abutment can be a detachable stainless steel keeper, or a keeper welded to the abutment as one

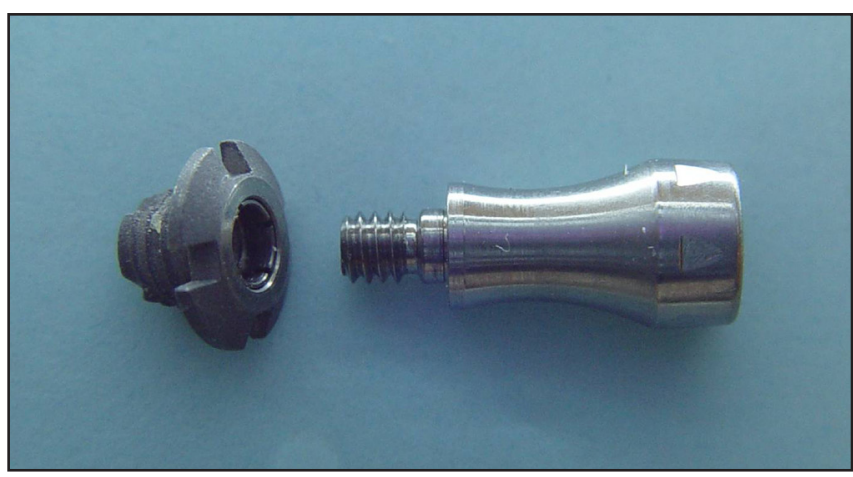

Figure 1. A typical $2.5 \mathrm{~mm}$ long craniofacial implant (Straumann USA, Inc., Andover, MA, USA), with its percutaneous titanium abutment, and integrated by welding, attached stainless steel keeper on right side (Technovent Ltd., Leeds, England).

unit. These units are often found as freestanding, and have magnets embedded in the prosthesis. A second type of retention system consists of bars connecting the implant abutments, with mechanical retention provided by clips embedded in the prosthesis. A third type of retention system consists of bars attached to the implant abutments, with stainless steel keepers attached to the bars, and magnets embedded in the prosthesis.

While imaging sequences can be optimized to minimize these artifacts, the development of simple alternative procedures to address the problem would be of clinical benefit. Removal of all metallic components above the level of the implant results in a considerable reduction in the $\mathrm{CT}$ artifact when studies of the head are performed (Figure 2B). Removal of all ferromagnetic components during MRI of any body part is also required due to potentially damaging tensile forces of unknown quantity at the implant to bone interface. This has previously been described for intraoral implants [15], and has been recommended by one prominent manufacturer of craniofacial implant magnetic components (Package insert, Magna-Cap Magnet Attachment System, Technovent Ltd., Leeds, England).

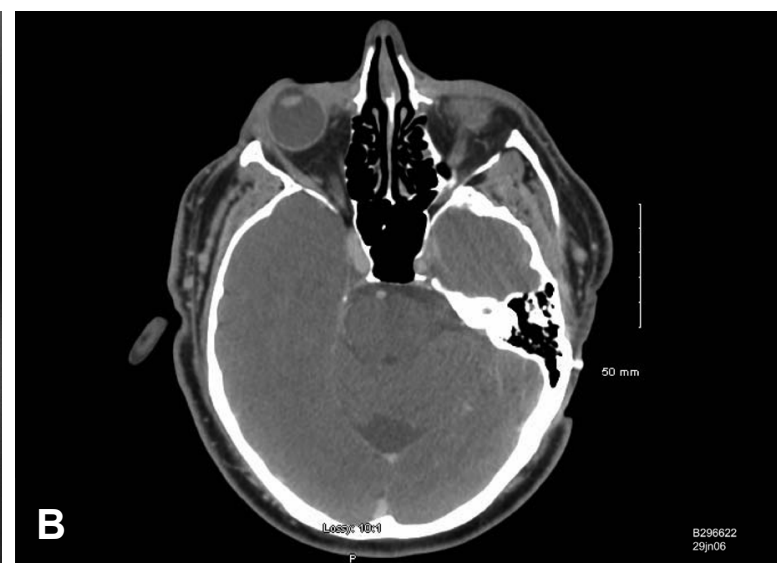

Figure 2. $\mathrm{A}=$ axial $\mathrm{CT}$ scan of a patient bearing a craniofacial implant without removal of prosthesis and embedded magnets, or abutments with stainless steel keepers, showing "starburst" artifact; B = axial CT scan directly through an extraoral implant, with attached titanium abutment, where all non-titanium supra-implant components were removed and no significant artifact is present. 
When an abutment is removed from cutaneous and subcutaneous tissue that is 3 or more millimeters thick, these tissues may contract very rapidly. During the time it takes to complete the CT or MRI, there can be significant contracture that would make it difficult and painful to replace the abutments. In some cases, a surgical procedure might be necessary to relocate the implant and insert the abutment.

The purpose of the present paper was to describe a method proposed by authors for eliminating cranial imaging artifacts in patients with craniofacial implants.

\section{MATERIAL AND METHODS}

Three patients wearing implant retained facial prostheses presented for CT or MRI studies. Patient I had an ear prosthesis containing magnets (Midi Lip Magnets, Technovent Ltd., Leeds, England), with percutaneous abutments composed of titanium with stainless steel keepers integrally attached (Magnabutment, Straumann USA, Inc., Andover, MA, USA), and required a CT study of the head (Figure 3A). Patient II was wearing a magnetically retained nose prosthesis (Midi Lip Magnets, Technovent Ltd., Leeds, England), with a gold alloy laser-welded superstructure (Round Bar, Uni $45^{\circ}$ OD Cylinder, Astra Tech, Molndal, Sweden) with attached stainless steel keepers laser-welded to the bar (Maxi Insert Keeper, Technovent Ltd., Leeds, England), attached to three titanium implant abutments (45 UniAbutments, Astra Tech, Molndal, Sweden) and required an MRI study of the spinal column (Figure 3B). Patient III was wearing a magnetically retained ear prosthesis containing four magnets (Midi Lip Magnets, Technovent Ltd., Leeds, England), on four implants with titanium abutments (Cochlear Americas, Centennial, CO, USA) and attached stainless steel keepers (Maxi Abutment Keeper, Technovent Ltd., Leeds, England), and required an MRI study of his shoulder region (Figure 3C). Using the appropriate wrenches supplied by the implant manufacturer, all supra-implant components were removed immediately prior to $\mathrm{CT}$ imaging of the head (Figure 3C). Where MRI of the head is to be performed, all supra-implant parts were also removed. Where MRI of other body areas is to be performed only magnetic and ferromagnetic parts need to be removed. Where the percutaneous tissues were greater then $3 \mathrm{~mm}$ thick, the openings were immediately filled with fast setting polyvinyl siloxane dental impression material (Elite Implant Medium Body Fast Set, Zhermack Inc., River Edge, NJ, USA) (Figure 4A). A medium or heavy-bodied consistency is recommended to prevent the material from flowing during setting. This material hardens quickly, thus preventing contracture of
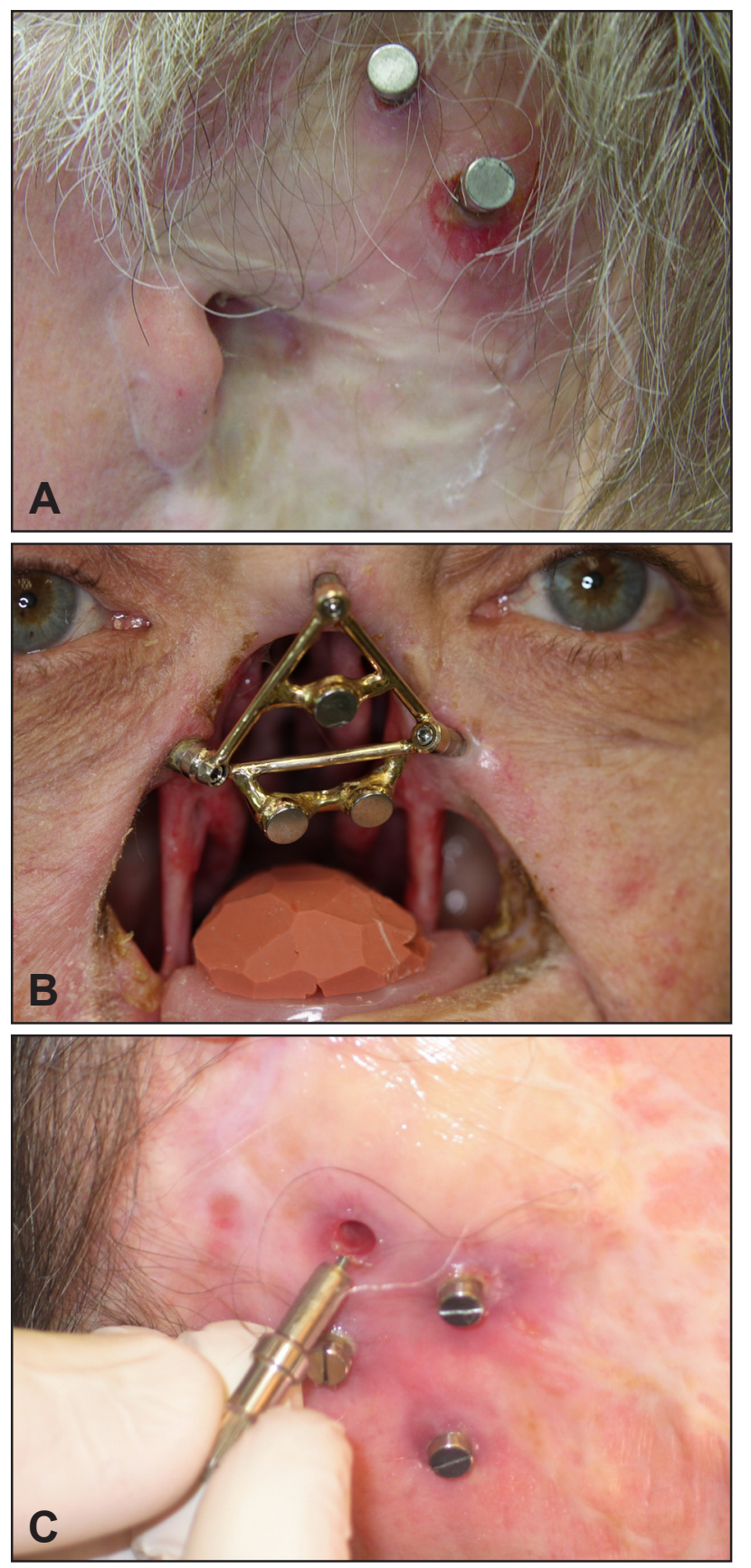

Figure 3. $A=$ patient $I$ has 2 craniofacial implants supporting titanium abutments that have stainless steel keepers attached to their ends; B = patient II has a complete superstructure for attachment of a nose prosthesis. It is supported by 3 implants, and fabricated from gold alloy, with attached stainless steel keepers; $\mathrm{C}=$ removing percutaneous abutment in patient III with attached stainless steel keeper, showing $7 \mathrm{~mm}$ thick cutaneous tissue.

the tissues around it. Because fluids can accumulate under the silicone plugs and possibly dislodge them, skin tape was placed over the plugs. The patients were then immediately sent for the imaging studies, and were asked to return for removal of the silicone plugs and reconnection of all superstructure hardware after imaging procedures were complete. The silicone plugs were easily removed with a dental explorer (Figure 4B). The percutaneous abutments were immediately replaced 

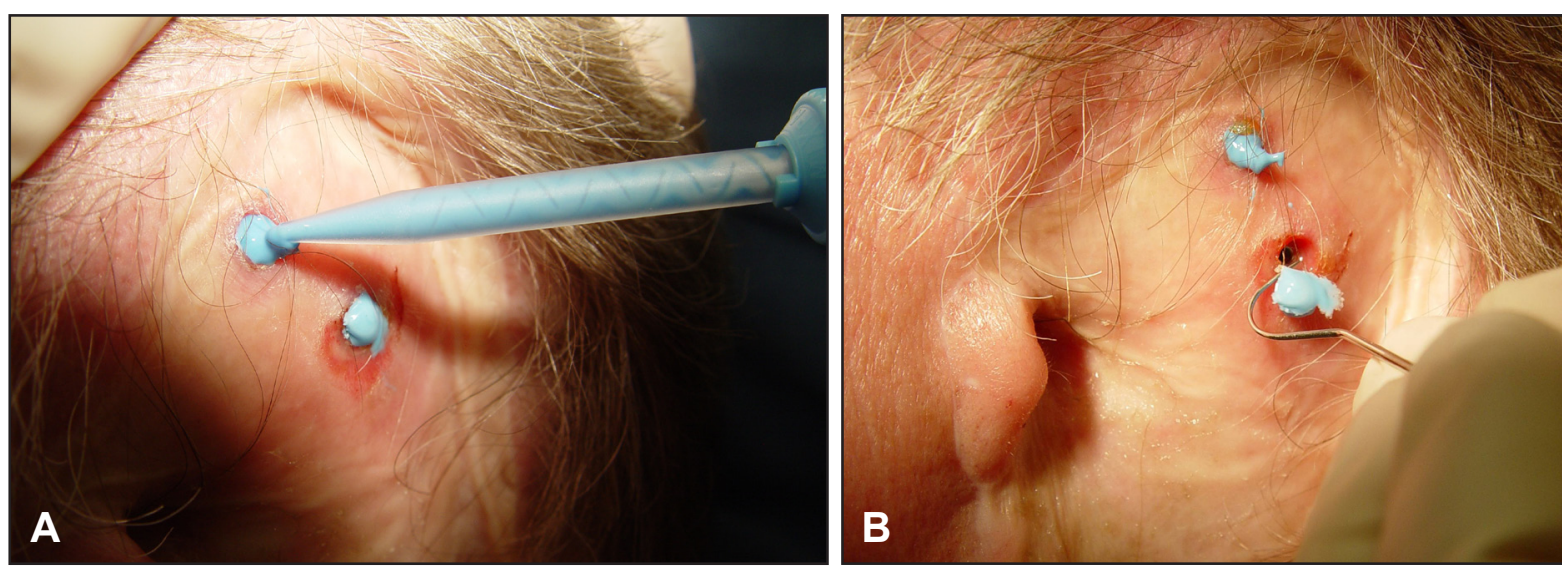

Figure 4. $\mathrm{A}$ = patient I, filling of the cutaneous openings with dental polyvinyl siloxane impression material; $\mathrm{B}=$ removal of silicone plugs immediately after completion of study, patient I.

and screwed into the implants which are at the bone level. If any additional superstructures were present, as in patient II (Figure 3B), these were then attached to the percutaneous abutments using the appropriate retaining screws.

\section{DISCUSSION}

Non-titanium metallic components attached to titanium craniofacial implants can cause localized artifacts and distortion of image quality in CT and MRI scans of the head. In addition, the potential damaging effects of tensile forces on bone surrounding implants caused by magnetic pull on ferromagnetic stainless steel keepers attached to craniofacial implants is unknown, and should be avoided. This latter effect is irrespective of what part of the body is receiving the MRI study. Titanium dental implants alone without superstructures, or titanium orthodontic brackets, have not shown to produce MRI artifact $[\underline{15}, \underline{16}]$.

It has been our experience that where short titanium percutaneous abutments have been left in place during $\mathrm{CT}$ of the head, no significant artifact has occurred (Figure 2B), so long as no non-titanium components are attached. There is evidence that larger titanium prostheses like knee or hip prostheses may cause significant CT beam hardening effect [17], however we have not found that to be the case with the small craniofacial implants or their titanium abutments alone (Figure 2B). Thus, the percutaneous abutments themselves need only be removed in those cases where a non-titanium stainless steel keeper component is an integral and non-removable part of the abutment, such as in the Magnabutment shown in Figure 1 (Magnabutment, Straumann USA, Inc., Andover, MA, USA). Imaging sequences can be optimized to minimize these artifacts, by temporary removal of the supra-implant components prior to imaging and filling of the tissue openings with fast setting polyvinyl siloxane impression material. In addition to eliminating the source of artifacts, this method importantly prevents contracture of percutaneous tissues upon removal of the implant abutments during imaging.

Removal of percutaneous abutments and superstructures is very technique sensitive. Specific wrenches made by the implant manufacturers must be used. Components should be reconnected using the torque recommended by their manufacturer. Screws can easily be fractured, and the actual implant-bone interface can be damaged if too much torque is applied. Internal threads in the implant can be irreversibly damaged by cross-threading if the angulation of the abutment is not correct while replacing it. An inventory of spare components should be available should any replacements be necessary during this procedure. It is for these reasons that these procedures should be performed only by the practitioners who placed the abutments and superstructures and fabricated the prostheses originally.

The time between removal of the components prescanning, and their reconnection should be minimal to eliminate the possibility of loss of the silicone plugs and the contracture of the percutaneous tissues. In our Institute, patients are always advised to have their scans performed here, even for those living out of town. This insures prompt and timely removal and reconnection by expert staff.

It should be mentioned that most dental impression materials are not sterile as supplied by the manufacturer. That is the reason for recommending the brand of polyvinyl siloxane used in this study [18]. This is the only material available in a unidose with all parts prepackaged and guaranteed sterile. 


\section{CONCLUSIONS}

In conclusion, it was developed by authors a protocol for removal of non-titanium components used for the retention of facial prostheses, in those patients who are to undergo computed tomography or magnetic resonance imaging scanning of the head, and for removal of ferromagnetic components for patients needing to be scanned with magnetic resonance imaging for any body part. Peri-abutment tissue contracture is prevented using polyvinyl siloxane. The procedure is simple, but must be performed by knowledgeable personnel, with appropriate instrumentation, and in a timely fashion.

\section{ACKNOWLEDGMENTS AND DISCLOSURE STATEMENTS}

The authors report no conflicts of interest related to this study.

\section{REFERENCES}

1. Tjellström A, Lindström J, Nylén O, Albrektsson T, Brånemark PI, Birgersson B, Nero H, Sylvén C. The bone-anchored auricular episthesis. Laryngoscope. 1981 May;91(5):811-5. [Medline: 7231030]

2. Tjellström A, Lindström J, Nylén O, Albrektsson T, Brånemark PI. Directly bone-anchored implants for fixation of aural epistheses. Biomaterials. 1983 Jan;4(1):55-7. [Medline: 6838958] [doi: 10.1016/0142-9612(83)90072-8]

3. Brånemark PI, Adell R, Breine U, Lindstrom J, Ohlsson A. Intra-osseous anchorage of dental prostheses. I. Experimental studies. Scand J Plast and Reconstr Surg 1969; 3: 81-100. [Medline: 4924041] [doi: 10.3109/02844316909036699]

4. Brånemark PI, Hansson BO, Adell R, Breine U, Lindström J, Hallén O, Ohman A. Osseointegrated implants in the treatment of the edentulous jaw. Experience from a 10-year period. Scand J Plast Reconstr Surg Suppl. 1977;16:1-132. [Medline: $\underline{356184}$ ]

5. Link TM, Berning W, Scherf S, Joosten U, Joist A, Engelke K, Daldrup-Link HE. CT of metal implants: reduction of artifacts using an extended CT scale technique. J Comput Assist Tomogr. 2000 Jan-Feb;24(1):165-72. [Medline: 10667677] [doi: 10.1097/00004728-200001000-00029]

6. Zannoni C, Viceconti M, Pierotti L, Cappello A. Analysis of titanium induced CT artifacts in the development of biomechanical finite element models. Med Eng Phys. 1998 Nov-Dec;20(9):653-9. [Medline: 10098609] [doi: $10.1016 / \mathrm{S} 1350-4533(98) 00076-9$ ]

7. Kumar R, Lerski RA, Gandy S, Clift BA, Abboud RJ. Safety of orthopedic implants in magnetic resonance imaging: an experimental verification. J Orthop Res. 2006 Sep;24(9):1799-802. [Medline: 16838376] [doi: 10.1002/jor.20213]

8. Matsuura H, Inoue T, Ogasawara K, Sasaki M, Konno H, Kuzu Y, Nishimoto H, Ogawa A. Quantitative analysis of magnetic resonance imaging susceptibility artifacts caused by neurosurgical biomaterials: comparison of $0.5,1.5$, and 3.0 Tesla magnetic fields. Neurol Med Chir (Tokyo). 2005 Aug;45(8):395-8; discussion 398-9. [Medline: 16127256] [doi: 10.2176/nmc.45.395] [FREE Full Text]

9. Graf H, Lauer UA, Berger A, Schick F. RF artifacts caused by metallic implants or instruments which get more prominent at $3 \mathrm{~T}$ : an in vitro study. Magn Reson Imaging. 2005 Apr;23(3):493-9. [Medline: 15862651] [doi: 10.1016/j.mri.2004.12.009]

10. 10. Matsuura H, Inoue T, Konno H, Sasaki M, Ogasawara K, Ogawa A. Quantification of susceptibility artifacts produced on high-field magnetic resonance images by various biomaterials used for neurosurgical implants. Technical note. J Neurosurg. 2002 Dec;97(6):1472-5. [Medline: 12507151] [doi: 10.3171/jns.2002.97.6.1472] [FREE Full Text]

11. Graf H, Lauer UA, Klemm T, Schnieder L, Schick F. [Artifacts in MRT caused by instruments and implants]. Z Med Phys. 2003;13(3):165-70. German. [Medline: 14562538]

12. Thomsen M, Schneider U, Breusch SJ, Hansmann J, Freund M. [Artefacts and ferromagnetism dependent on different metal alloys in magnetic resonance imaging. An experimental study]. Orthopade. 2001 Aug;30(8):540-4. German. [Medline: 11552395] [doi: 10.1007/s001320170063]

13. Shellock FG. Metallic neurosurgical implants: evaluation of magnetic field interactions, heating, and artifacts at 1.5-Tesla. J Magn Reson Imaging. 2001 Sep;14(3):295-9. [Medline: 11536406] [doi: 10.1002/jmri.1185]

14. Goiato MC, Delben JA, Monteiro DR, dos Santos DM. Retention systems to implant-supported craniofacial prostheses. J Craniofac Surg. 2009 May;20(3):889-91. Review. [Medline: 19349908] [doi: 10.1097/SCS.0b013e3181a14bcb]

15. Devge C, Tjellström A, Nellström H. Magnetic resonance imaging in patients with dental implants: a clinical report. Int J Oral Maxillofac Implants. 1997 May-Jun;12(3):354-9. [Medline: 9197100]

16. Elison JM, Leggitt VL, Thomson M, Oyoyo U, Wycliffe ND. Influence of common orthodontic appliances on the diagnostic quality of cranial magnetic resonance images. Am J Orthod Dentofacial Orthop. 2008 Oct;134(4):563-72. Erratum in: Am J Orthod Dentofacial Orthop. 2009 Jan;135(1):8. [Medline: 18929275] [doi: 10.1016/j.ajodo.2006.10.038] 
17. Feng Z, Ziv I, Rho J, Han S, Fishkin Z. Effects of titanium prosthesis, offset and size of field of view on bone mineral density measurements using quantitative computed tomography. Br J Radiol. 2000 May;73(869):498-503. [Medline: 10884746] [FREE Full Text]

18. Coppi C, Paolinelli Devincenzi C, Bortolini S, Consolo U, Tiozzo R. A new generation of sterile and radiopaque impression materials: an in vitro cytotoxicity study. J Biomater Appl. 2007 Jul;22(1):83-95. Epub 2006 Oct 25. [Medline: 17065163] [doi: $10.1177 / 0885328206071928$ ]

\section{To cite this article:}

Sullivan M, Rossitto R, Casey DM. Prevention of Cutaneous Tissue Contracture During Removal of Craniofacial Implant Superstructures for CT and MRI Studies.

J Oral Maxillofac Res 2010;1(2):e4

URL: http://www.ejomr.org/JOMR/archives/2010/2/e4/e4ht.pdf

doi: $10.5037 /$ jomr.2010.1204

Copyright (C) Sullivan M, Rossitto R, Casey DM. Accepted for publication in the JOURNAL OF ORAL \& MAXILLOFACIAL RESEARCH (http://www.ejomr.org), 4 April 2010.

This is an open-access article, first published in the JOURNAL OF ORAL \& MAXILLOFACIAL RESEARCH, distributed under the terms of the Creative Commons Attribution-Noncommercial-No Derivative Works 3.0 Unported License, which permits unrestricted non-commercial use, distribution, and reproduction in any medium, provided the original work and is properly cited. The copyright, license information and link to the original publication on (http://www.ejomr.org) must be included. 